\title{
CONSTITUENT AND ANTIHYPERURICEMIC ACTIVITY OF STELECHOCARPUS BURAHOL LEAVES SUBFRACTIONS
}

\author{
TITIK SUNARNII,2*, IRDA FIDRIANNY ${ }^{1}$, MARIA IMMACULATA IWO ${ }^{3}$, KOMAR RUSLAN WIRASUTISNA ${ }^{1}$ \\ ${ }^{1}$ Pharmaceutical Biology Research Group, School of Pharmacy, Bandung Institute of Technology, Indonesia. ${ }^{2}$ Department of \\ Pharmaceutical Biology, Faculty of Pharmacy, Setia Budi University, Indonesia. ${ }^{3}$ Pharmacology-Clinical Pharmacy Research Group, School \\ of Pharmacy, Bandung Institute of Technology, Indonesia. Email: titiksunarni@yahoo.co.id
}

Received: 10 January 2017, Revised and Accepted: 20 January 2017

ABSTRACT

Objective: The goal of this research was to evaluate antihyperuricemic activity of Stelechocarpus burahol leaves subfractions and isolate its chemical constituent of active subfraction.

Methods: Ethyl acetate fraction from S. burahol extract was subfractionated by vacuum liquid chromatography, and the active subfractions were further subfractionated by classic column chromatography using isocratic eluent, followed by isolated chemical constituent from active subfraction. Hyperuricemic rat model was induced by given potassium oxonate intraperitoneally. The inhibitory effect of subfractions on the xanthine oxidase (XO) activity was determined using ultraviolet-visible spectrophotometry method.

Results: Subfractions E.3, E.4, and E.5 significantly (p<0.05) reduced the serum uric acid (UA) level 43\%, 46\%, and 33\%, respectively. The E.3, E.4, and E.5 have showed very weak XO inhibitory activity. Subfraction E.3.2 and E.4.3 significantly (p<0.05) reduced the serum UA level $29 \%$ and $38 \%$, respectively, however still very weak effect on XO activity. Chemical constituent which was isolated from subfraction E.4.3 was kaempferol-3-0-rhamnoside.

Conclusion: The subfractions of ethyl acetate fraction had antihyperuricemic activity in vivo but less effect on XO activity in vitro. Isolated compound in active antihyperuricemic of subfraction E.4.3 was kaempferol-3-0-rhamnoside.

Keywords: Stelechocarpus burahol, Subfraction, Antihyperuricemic, Xanthine oxidase inhibitory activity, Kaempferol-3-0-rhamnoside.

(C) 2017 The Authors. Published by Innovare Academic Sciences Pvt Ltd. This is an open access article under the CC BY license (http://creativecommons. org/licenses/by/4. 0/) DOI: http://dx.doi.org/10.22159/ajpcr.2017.v10i4.17021

\section{INTRODUCTION}

Hyperuricemia means high levels of uric acid (UA) in the blood, a condition considered to be closely associated with increasing risks for developing gout, cardiovascular diseases, hypertension, and metabolic syndrome $[1,2]$. The risk of developing gout is closely related to the serum UA level. The 5-year risk of gout varied from $0.6 \%$ for those with a serum UA level $>7 \mathrm{mg} / \mathrm{dl}$ to $30.5 \%$ for those with a level $>10 \mathrm{mg} / \mathrm{dl}$ [3]. UA is the end-product of purine metabolism in human with the loss uricase. Xanthine oxidase (XO) converts hypoxanthine to xanthine and xanthine to UA [4]. The XO activity derived species reactive oxygen species/reactive nitrogen species (ROS/RNS). ROS and RNS can generate ischemic-reperfusion (IR) injury [5].

Currently available antihyperuricemic agents for chronic gout can be classified into three categories: (i) uricostatic (XO inhibitor), for example, allopurinol and febuxostat, (ii) uricosuric, for example, benzbromarone, sulfinpyrazone, and probenecid, and (iii) uricolytic, for example, uricozyme and rasburicase [6,7]. Despite advances in the use of antihyperuricemic agents for hyperuricemia and gout treatment, however, adverse effects such as severe hypersensitivity reactions associated with allopurinol and severe hepatotoxicity risk of benzbromarone limit their therapy usage [8].

The medicinal use of botanical plants is gaining renewed interest in connection with the sustaining of health and clinical disorder. Scientists have studied to explore the potent antihyperuricemic from a wide variety of traditional herbal plants. Many plants have potential as medicinal plants for gout treatment [9]. Stelechocarpus burahol (Bl.) is a traditionally plant for antihyperuricemic and gout [10]. The trees are widely distributed in Thailand, Vietnam, Malaysia, Indonesia (Java, Bali, Sumatra, and Borneo) [11]. The local name in Indonesia is burahol, turalak (Sunda) or kepel (Jawa) [12]. A previous study revealed that ethanolic extract from $S$. burahol leaves was one of the samples which had a potent antihyperuricemic in vivo compared to Annona squamosa, Annona muricata, and Annona reticulata [13]. N-hexane and ethyl acetate fractions of $S$. burahol leaves decreased serum UA level in rats [14]. Furthermore, the $S$. burahol leaves contained flavonoid and terpenoid $[10,15]$. Many researchers reported that some of flavonoid compounds have strong XO inhibitory and antihyperuricemic in vivo activity. However, it is not clear which compounds are active in the extract, fraction and subfraction. This study aimed to evaluate the potent of subfractions of $S$. burahol in lowering of UA. The activity was evaluated by in vivo potassium-oxonate-induced acute hyperuricemia and in vitro XO inhibitory activity assay. Furthermore, phytochemical compound of active subfraction was isolated and identified.

\section{METHODS}

Materials

Xanthine, XO, potassium dihydrogen phosphate, dimethyl sulfoxide (DMSO), potassium oxonate were purchased from Sigma Chemicals Co. Allopurinol was obtained from Ifars Pharmaceutical Laboratories. The UA kit was purchased from Sclavo Diagnostic. Silica gel $60 \mathrm{H}$ for thin-layer chromatography and silica gel 60 $(0.063-0.200 \mathrm{~mm})$ for column chromatography from Merck were used.

\section{Instrument and reagent}

Nuclear magnetic resonance (NMR) spectra $\left({ }^{1} \mathrm{H}-\mathrm{NMR}\right.$ and ${ }^{13} \mathrm{C}-\mathrm{NMR}$ spectra taken at $500 \mathrm{MHz}$ and $125 \mathrm{~Hz}$ of Agilent $500 \mathrm{MHz}$ by Consol Sistem) were recorded in deuterated solvent using methanol. MS spectra were measured using ultra-performance liquid chromatography quadrupole time-of-flight mass spectrometry/mass spectrometry (Waters) ESI positive with mobile phase $\mathrm{A}\left(\mathrm{H}_{2} \mathrm{O}, 0.1 \%\right.$ formic acid) and 
B (acetonitrile, 0.1\% formic acid), gradient method. Ultraviolet (UV) spectra were identified using spectrodensitometry (Camag Thin-layer Chromatography Scanner).

\section{Animal}

Male Wistar rats weighed 170-200 g (age, 7-8 weeks) were obtained from the animal laboratory (School of Pharmacy, Bandung Institute of Technology). The rats were allowed to adapt to their environment at a constant temperature of $25^{\circ} \mathrm{C}$ for a week before being used. They were given free access to feed standard pellets and water during the study. All the procedures were approved by Animal Ethics Committee, Bandung Institute of Technology.

\section{Plant materials}

Leaves of $S$. burahol was collected from Central Java, Indonesia, and determined in School of Life Science and Technology, Bandung Institute of Technology. The materials were washed, wet sortation, dried, and grinded into powder.

\section{Preparation of the extract and fractionation}

The dried leaves powder of $S$. burahol $(6 \mathrm{~kg})$ was macerated with $30 \mathrm{~L}$ ethanol $96 \%$ for 5 days at room temperature. After 5 days, the mixture was filtered and the residue washed using ethanol and treated for 5 days of the same treatment as before. The extract was concentrated under reduced pressure to yield a residue (9.2\%). The ethanolic extract was then suspended with Aquadest and extracted successively with equal volume of $n$-hexane and ethyl acetate. Each fraction was then concentrated under reduced pressure to obtain n-hexane fraction (33\%), ethyl acetate fraction (12\%), and aqueous fraction (32\%). The ethyl acetate fraction was subfractionated by vacuum liquid chromatography. The column was packed with silica gel $\mathrm{H}$ and then eluted by mobile phase that was fifty eluent system n-hexane, ethyl acetate, and methanol, with increasing polarity $(10: 0: 0 \rightarrow 0: 0: 1 \mathrm{v} / \mathrm{v})$, to divide the fraction into seven subfractions (E.1-E.7). Each subfraction E.3 (1.0 g) and E.4 (0.7 g) was then subfractionated by classical column chromatography by isocratic elution using chloroformmethanol (8:2) to give three and four subfractions (E.3.1-E.3.3 and E.4.1-E.4.4). Subfraction E.4.3 (184 $\mathrm{mg}$ ) was purified by preparative paper chromatography with mobile phase acetic acid $10 \%$ to give three subfractions (E.4.3.1-E.4.3.3). Subfraction E.4.3.2 was then purified by preparative thin layer chromatography with mobile phase chloroformmethanol (8:2) to obtain compound R (5.7 mg).

\section{In vivo antihyperuricemic activity}

\section{Animal model and drug administration}

Before being used in the experiment, the rats fasted 1 day. The animals were carried to the laboratory at least $1 \mathrm{hr}$ before the experiment begins. Water was withdrawn from the animals $1 \mathrm{hr}$ before drug administration. The experiment was conducted using modified Liu's method [16]. Rats were divided randomly into normal control, hyperuricemic control, standard (allopurinol), and sample groups $(\mathrm{n}=6 \mathrm{each})$. Potassium oxonate, subfractions, and allopurinol were dispersed in $0.3 \%$ carboxymethylcellulose sodium. The dose of subfraction was calculated from percentage of yielding subfraction. The subfractions were given orally to rats. Allopurinol $(10 \mathrm{mg} / \mathrm{kg})$ was used as standard. The volume of the suspension which was administered based on body weight of rat. Before potassium oxonate administration, whole blood was collected for determining serum UA level on $0 \mathrm{~h}$. Briefly, $1 \mathrm{~h}$ before the drug administration, all rats were injected intraperitoneally with potassium oxonate $250 \mathrm{mg} / \mathrm{kg}$ to increase the serum UA level, except normal control group. Whole blood samples were collected from rats by tail vein bleeding in duration $1^{\text {st }} \mathrm{h}$ to $3^{\text {rd }} \mathrm{h}$ for obtaining UA level on $1^{\text {st }}, 2^{\text {nd }}$, and $3^{\text {rd }} \mathrm{h}$ after drug administration.

\section{UA assay}

The blood was allowed to clot for 30 minutes at room temperature and then centrifuged at $10.000 \times g$ for 7 minutes to obtain the serum. Serum was stored at $-20^{\circ} \mathrm{C}$ until assayed. Serum UA level was determined by enzymatic colorimetric method using a standard diagnostic kit.

\section{In vitro $\mathrm{XO}$ inhibitory activity}

XO inhibitory activity was performed based on Umamaheswari [17] and Abdullahi [18] with minor modification. $1 \mathrm{ml}$ fraction $(25-200 \mu \mathrm{g} / \mathrm{ml})$ was mixed $0.9 \mathrm{ml}$ phosphate buffer $50 \mathrm{mM}\left(\mathrm{pH} 7.5\right.$ at $\left.25^{\circ} \mathrm{C}\right)$ and $0.1 \mathrm{ml}$ XO enzyme solution ( 0.1 unit/ml in phosphate buffer, $\mathrm{pH} 7.5$ ) and preincubated on for 15 minutes at $25^{\circ} \mathrm{C} .2 \mathrm{ml}$ of xanthine solution $0.15 \mathrm{mM}$ (prepared fresh) was added to the mixture and then incubated for 30 minutes at $25^{\circ} \mathrm{C}$. The reaction was then stopped by adding $1 \mathrm{ml} 1 \mathrm{~N}$ hydrochloric acid, and the absorbance was measured at $\lambda 287 \mathrm{~nm}$ using UV-Vis spectrophotometer. Different concentrations of the fraction $(25-200 \mu \mathrm{g} / \mathrm{ml})$ were dissolved in DMSO. Allopurinol $(0.2-1.6 \mu \mathrm{g} / \mathrm{ml})$ was used as the positive control. All of the experiments were conducted in triplicate. The XO inhibitory activity of fraction was assessed as the inhibitory percentage (\%):

Inhibition $(\%)=\left\{\frac{(A-B)-(C-D)}{(A-B}\right\} \times 100$

where A is the activity of the enzyme without the extract, B is the control of A without the extract and enzyme, and C and D are the activity of the extract with and without XO, respectively. The assay was done in triplicate, and $\mathrm{IC}_{50}$ values were calculated from the percentage of inhibition $50 \%$.

\section{Statistical analysis}

Results showed and represent the mean \pm standard deviation. The significant difference was statistically calculated by the analysis of variance (one-way), followed by Tukey's post-hoc test. Statistical significant was set at $\mathrm{p}<0.1,0.05$, and 0.01 .

\section{RESULTS AND DISCUSSION}

\section{Antihyperuricemic activity of subfractions E.1-E.7}

The antihyperuricemic activity of subfractions E.1-E.7 on hyperuricemic rats using potassium oxonate is shown in Table 1. In the present study, potassium oxonate, a well-known uricase inhibitor, was used to induce hyperuricemia in rats [19]. The serum UA level of chemically induced hyperuricemic rats was significantly higher $(\mathrm{p}<0.01)$ than normal control, which indicated that hyperuricemic rat model has been successfully established. Treatment by subfractions E.1-E.7 can reduce serum UA level of hyperuricemic rats, and only E.3 (43\%), E.4 (46\%), and E.5 (33\%) showed significantly different compared to hyperuricemic control $(p<0.05)$. The dose of subfraction was calculated using response profile of ethyl acetate fraction and percentage of yielding subfractions. This was assumed that subfractions which obtained from bioactivityguided subfractionation will contain more bioactive constituents than the crude ethanol extract or ethyl acetate fraction and thus will show inhibition higher than the crude drugs of ethanol extract [13] and ethyl acetate fraction [14].

The XO inhibitory activity of subfractions E.1-E.7 was evaluated by the xanthine-XO enzymatic system. The influence of subfraction on $\mathrm{XO}$ activity was calculated by decreasing production of UA, which was measured by UV-Vis spectrophotometry. The XO inhibitory activity of subfractions which were resulted from subfractionation of ethyl acetate fraction by vacuum liquid chromatography is presented in Table 2 . Those subfractions E.1-E.7 expressed low and no effect on XO inhibitory activity. Subfractions E.1-E.6 elicited a dose-dependent inhibition of XO enzyme activity. At concentration of $200 \mathrm{~g} / \mathrm{ml}$, the highest activity was given by E.3 subfraction, followed by E.4 and E.2 subfractions. These results were compared to allopurinol, which revealed $48.69 \pm 1.82 \%$ inhibition at $2 \mu \mathrm{g} / \mathrm{ml}$ concentration (Table 1 ). The all of subfractions had $\mathrm{IC}_{50}$ more than $200 \mu \mathrm{g} / \mathrm{ml}$, which were categorized as very weak activity.

Antihyperuricemic activity of subfractions E.3.1-E.4.4

The antihyperuricemic activity of subfractions E.3.1-E.4.4, which were resulted from subfractionation of subfractions E.3 and E.4, is given in Table 3. 
In the present study, the serum UA level of hyperuricemic group increased more than 1.5-fold compared to normal control. The rat which was induced by potassium oxonate can serve as a useful hyperuricemia animal model to evaluate serum UA levels of sample. The oral treatment by subfractions E.3.1-E.4.4 could reduce serum UA level of hyperuricemic rats compared to hyperuricemic control; however, only E.3.2 $(20 \mathrm{mg} / \mathrm{kg})$, E.4.2 (8 mg/kg), and E. $4.3(8 \mathrm{mg} / \mathrm{kg})$ subfractions demonstrated antihyperuricemic activity $(p<0.05)$. The rats were treated by subfraction E.4.3 had UA levels that were significantly reduced $38 \%$ followed by E.3.2 29\% compared to hyperuricemic group $(p<0.01)$. On the other hand, serum UA level of hyperuricemic group and the rats which were treated by subfractions E.3.1, E.3.3, E.4.1, and E. 4.4 were not significantly different.

All subfractions of E. 3 and E.4 presented a dose-dependent inhibition of XO enzyme activity. The results demonstrated that subfractions E.3.1-E.4.4 possessed XO inhibitory activity as shown in Table 4. Among the obtained subfractions, the subfraction E.3.2 at concentration of $200 \mu \mathrm{g} / \mathrm{ml}$, the highest activity was given by E.3.2 (63.79\%), followed E.4.4 (43.20\%) and E.4.3 (41.46\%). The subfraction E.3.2 gave XO inhibitory activity with $\mathrm{IC}_{50} 128.39 \pm 20.21 \mu \mathrm{g} / \mathrm{ml}$, while the other subfractions which were resulted by classical column chromatography of E. 3 and E. 4 gave $\mathrm{IC}_{50}$ more than $200 \mathrm{ug} / \mathrm{ml}$. The XO inhibitory activity of subfractions E.3.1-E.4.4 was compared to allopurinol, which is clinically used as a drug for the XO inhibitor [20]. Allopurinol as standard showed very strong inhibitory activity with $\mathrm{IC}_{50} 1.08 \pm 0.04 \mu \mathrm{g} / \mathrm{ml}$ (Table 4).

The subfractions E.3.1-E.4.4 which were resulted from subfractionation of E.3 and E.4 subfractions by classical column chromatography had antihyperuricemic activity in vivo but had less XO inhibitory activity in vitro. The previous studies also found that ethanolic extract of S. burahol exposed lower XO inhibitory activity but had significant antihyperuricemic activity in vivo $[14,21]$.

Table 1: UA level of hyperuricemic rats before and after giving subfractions (E.1-E.7)

\begin{tabular}{|c|c|c|c|c|c|}
\hline \multirow[t]{2}{*}{ Group } & \multirow[t]{2}{*}{ Dose (mg/kg) } & \multicolumn{4}{|c|}{ Serum UA level (mg/dl) } \\
\hline & & $\mathbf{0 ~ h}$ & $1 \mathrm{~h}$ & $2 \mathrm{~h}$ & $3 \mathbf{h}$ \\
\hline Normal & & $2.62 \pm 0.33$ & $2.42 \pm 0.37^{r}$ & $2.34 \pm 0.28^{r}$ & $2.46 \pm 0.39^{r}$ \\
\hline Hyperuricemic & & $2.53 \pm 0.19$ & $3.61 \pm 0.21^{\mathrm{cz}}$ & $3.92 \pm 0.22^{\mathrm{cz}}$ & $3.86 \pm 0.17^{\mathrm{cz}}$ \\
\hline Allopurinol & 10 & $2.46 \pm 0.36$ & $1.82 \pm 0.40^{\mathrm{r}}$ & $1.93 \pm 0.16^{\mathrm{r}}$ & $2.20 \pm 0.51^{\mathrm{r}}$ \\
\hline E.1 & 35 & $2.67 \pm 0.26$ & $3.05 \pm 0.40^{z}$ & $3.46 \pm 0.15^{\mathrm{cpz}}$ & $3.54 \pm 0.20^{\mathrm{bz}}$ \\
\hline E. 2 & 14 & $2.37 \pm 0.49$ & $2.59 \pm 0.25^{\mathrm{pz}}$ & $3.14 \pm 0.20^{\mathrm{cz}}$ & $3.16 \pm 0.46^{\mathrm{cz}}$ \\
\hline E.4 & 8 & $2.42 \pm 0.14$ & $1.94 \pm 0.82^{\mathrm{r}}$ & $2.72 \pm 0.61^{\mathrm{bqz}}$ & $2.89 \pm 0.60^{y}$ \\
\hline E.5 & 8 & $2.40 \pm 0.59$ & $2.42 \pm 0.43^{\mathrm{rz}}$ & $3.37 \pm 0.35^{\mathrm{bz}}$ & $2.93 \pm 0.78^{x}$ \\
\hline E. 6 & 7 & $2.21 \pm 0.38$ & $2.60 \pm 0.21^{\mathrm{pz}}$ & $2.96 \pm 0.56^{\mathrm{cz}}$ & $2.77 \pm 0.40^{y}$ \\
\hline E.7 & 10 & $2.30 \pm 0.40$ & $2.70 \pm 0.64^{\mathrm{az}}$ & $3.18 \pm 0.37^{\mathrm{cz}}$ & $2.83 \pm 0.40^{\mathrm{ax}}$ \\
\hline
\end{tabular}

${ }^{a} \mathrm{p}<0.1 ;{ }^{b} \mathrm{p}<0.05 ;{ }^{\mathrm{c}} \mathrm{p}<0.01$ compared to normal control. ${ }^{\mathrm{p}} \mathrm{p}<0.1 ;{ }^{\mathrm{q}} \mathrm{p}<0.05 ;{ }^{\mathrm{p}} \mathrm{p}<0.01$ compared to hyperuricemic control. ${ }^{\mathrm{p}} \mathrm{p}<0.1 ;{ }^{\mathrm{y}} \mathrm{p}<0.05 ;{ }^{\mathrm{z}} \mathrm{p}<0.01$ compared to allopurinol. UA: Uric acid

Table 2: In vitro xanthine oxidase inhibitory activity of subfractions (E.1-E.7)

\begin{tabular}{|c|c|c|c|c|c|}
\hline \multirow[t]{2}{*}{ Group } & \multicolumn{4}{|c|}{ Percentage of xanthine oxidase inhibition $(\mu \mathrm{g} / \mathrm{ml})$} & \multirow[t]{2}{*}{$\mathrm{IC}_{50}(\mu \mathrm{g} / \mathrm{ml})$} \\
\hline & 25 & 50 & 100 & 200 & \\
\hline E.1 & $2.93 \pm 2.5$ & $6.56 \pm 3.47$ & $7.50 \pm 2.67$ & $10.10 \pm 1.87$ & $>200$ \\
\hline E. 2 & $7.90 \pm 2.20$ & $12.55 \pm 3.96$ & $13.83 \pm 4.57$ & $18.22 \pm 7.78$ & $>200$ \\
\hline E. 3 & $13.00 \pm 3.50$ & $21.36 \pm 4.01$ & $28.22 \pm 3.61$ & $42.02 \pm 4.05$ & $>200$ \\
\hline E. 4 & $3.46 \pm 2.06$ & $8.38 \pm 5.91$ & $13.82 \pm 3.84$ & $19.84 \pm 4.90$ & $>200$ \\
\hline E. 5 & $2.82 \pm 2.78$ & $4.53 \pm 2.36$ & $4.88 \pm 2.93$ & $9.10 \pm 3.70$ & $>200$ \\
\hline E. 6 & $6.70 \pm 1.82$ & $6.35 \pm 2.40$ & $6.95 \pm 2.99$ & $9.27 \pm 3.51$ & $>200$ \\
\hline E.7 & $12.08 \pm 7.08$ & $5.55 \pm 7.76$ & $-5.84 \pm 2.78$ & $3.47 \pm 22.50$ & - \\
\hline \multirow[t]{3}{*}{ Allopurinol } & \multicolumn{4}{|c|}{ Percentage of xanthine oxidase inhibition $(\mu \mathrm{g} / \mathrm{ml})$} & $2.16 \pm 0.53$ \\
\hline & 0.2 & 0.5 & 1 & 2 & \\
\hline & $10.62 \pm 1.39$ & $16.73 \pm 2.97$ & $27.69 \pm 7.95$ & $48.69 \pm 10.82$ & \\
\hline
\end{tabular}

Table 3: UA level of hyperuricemic rats before and after giving subfractions (E.3.1-E.4.4)

\begin{tabular}{|c|c|c|c|c|c|}
\hline \multirow[t]{2}{*}{ Group } & \multirow[t]{2}{*}{ Dose (mg/kg) } & \multicolumn{4}{|c|}{ Serum UA level (mg/dl) } \\
\hline & & $0 \mathbf{h r}$ & $1 \mathrm{hr}$ & $2 \mathrm{hr}$ & $3 \mathbf{h r}$ \\
\hline Normal & & $2.62 \pm 0.33$ & $2.42 \pm 0.37^{r}$ & $2.34 \pm 0.28^{q}$ & $2.46 \pm 0.39^{r}$ \\
\hline Hyperuricemic & & $2.80 \pm 0.43$ & $3.61 \pm 0.32^{\mathrm{cz}}$ & $4.43 \pm 0.68^{\mathrm{cx}}$ & $4.16 \pm 0.95^{\mathrm{cz}}$ \\
\hline Allopurinol & 10 & $2.46 \pm 0.36$ & $1.82 \pm 0.40^{\mathrm{qx}}$ & $1.93 \pm 0.16^{q}$ & $2.20 \pm 0.51^{\mathrm{r}}$ \\
\hline E.3.1 & 12 & $2.83 \pm 0.24$ & $2.99 \pm 0.45^{z}$ & $3.79 \pm 0.65^{c z}$ & $3.78 \pm 0.68^{y}$ \\
\hline E.3.2 & 20 & $2.87 \pm 0.28$ & $2.55 \pm 0.32^{\text {ary }}$ & $3.37 \pm 0.18^{\mathrm{pz}}$ & $3.56 \pm 0.89^{y}$ \\
\hline E.3.3 & 5 & $2.72 \pm 0.65$ & $2.99 \pm 0.37^{z}$ & $3.97 \pm 0.48^{\mathrm{cz}}$ & $3.89 \pm 0.57^{\mathrm{bz}}$ \\
\hline E.4.1 & 12 & $2.98 \pm 0.14$ & $2.96 \pm 0.42^{z}$ & $3.74 \pm 0.72^{\mathrm{cz}}$ & $4.04 \pm 0.92^{\mathrm{bz}}$ \\
\hline E.4.2 & 8 & $2.82 \pm 0.28$ & $2.80 \pm 0.45^{\mathrm{qz}}$ & $3.75 \pm 0.84^{\mathrm{cz}}$ & $4.08 \pm 0.60^{c z}$ \\
\hline E.4.3 & 8 & $2.57 \pm 0.40$ & $2.23 \pm 0.38^{\mathrm{r}}$ & $3.53 \pm 0.48^{\mathrm{bz}}$ & $3.72 \pm 0.63^{y}$ \\
\hline E.4.4 & 6 & $2.76 \pm 0.30$ & $2.93 \pm 0.26^{\mathrm{pz}}$ & $4.13 \pm 0.51^{\mathrm{bz}}$ & $4.08 \pm 0.75^{\mathrm{cz}}$ \\
\hline
\end{tabular}

UA: Uric acid. Keterangan: ${ }^{a} p<0.1{ }^{b} p<0.05 ;{ }^{p} p<0.01$ compared to normal control. ${ }^{p} p<0.1 ;{ }^{q} p<0.05 ;{ }^{r} p<0.01$ compared to hyperuricemic control. ${ }^{x} p<0.1 ;{ }^{y} p<0.05 ;{ }^{z} p<0.01$ compared to allopurinol 
Structure elucidation

The subfraction E.4.3 of $S$. burahol leaves was purified by preparative paper chromatography and repurified by preparative thin layer chromatography. Compound $\mathrm{R}$ was obtained as a pale yellow amorphous powder. The UV spectrum of R showed $\lambda \max$ at $268 \mathrm{~nm}$ and $348 \mathrm{~nm}$ which was suggested as flavonoid [22]. Table 5 revealed the chemical shift value of ${ }^{1} \mathrm{H}$ and ${ }^{13} \mathrm{C}$-NMR for compound $\mathrm{R}$. The ${ }^{1} \mathrm{H}$ and ${ }^{13} \mathrm{C}$-NMR values of all carbons were assigned on the basic of heteronuclear single quantum coherence (HSQC) and heteronuclear multiple bond correlation (HMBC)

Based on the characterization and identification by UV-visible spectrophotodensitometry, ${ }^{1} \mathrm{H}-\mathrm{NMR},{ }^{13} \mathrm{C}-\mathrm{NMR}, \mathrm{HSQC}$, and $\mathrm{HMBC}$ demonstrated that isolate was predicted as kaempferol-3-0rhamnoside $\left(\mathrm{C}_{21} \mathrm{H}_{20} \mathrm{O}_{10}\right)$. It was also confirmed by mass spectrum which presented molecular ion $\left[\mathrm{M}+\mathrm{H}^{+}\right]$at 433.38 , while the molecular weight of kaempferol-3-O-rhamnoside $\left(\mathrm{C}_{21} \mathrm{H}_{20} \mathrm{O}_{10}\right)$ is $432.38 \mathrm{~g} / \mathrm{mol}$. Therefore, it can be concluded that isolate was kaempferol-3-0-rhamnoside (Fig. 1).

The isolate of active subfraction, kaempferol-3-0-rhamnoside, may be active compound. The structure-activity relationships exhibited that flavones and flavonols with a-7-hydroxyl group such as chrysin, luteolin, kaempferol, quercetin, myricetin, and isorhamnetin inhibited $\mathrm{XO}$ activity at low concentration. The previous research presented that kaempferol showed XO inhibitory activity at $\mathrm{IC}_{50}$ value $0.67 \mu \mathrm{M}$ [23].
Ahmad [24] denoted that kaempferol had XO inhibitory activity at IC $_{50} 1.87 \mu \mathrm{g} / \mathrm{ml}$ whereas the IC $_{50}$ of kaempferol-3-O- $ß-D$-glucopyranoside and kaempferol-3-0-(4-0-galloyl)- $\alpha$-L-arabinopyranoside was 11.74 and $13.96 \mu \mathrm{g} / \mathrm{ml}$, respectively. The main inhibition mechanism of

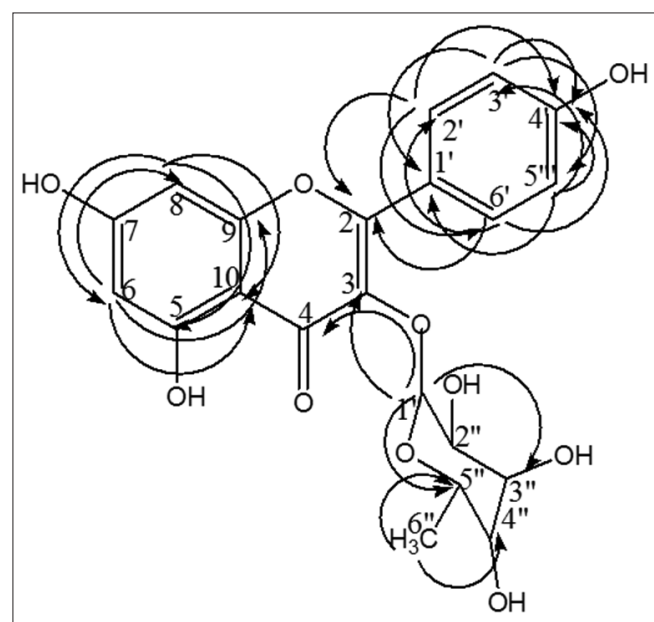

Fig. 1: Heteronuclear single quantum coherence and heteronuclear multiple bond correlation of compound $\mathbf{R}$

Table 4: In vitro xanthine oxidase inhibitory activity of subfractions (E.3.1-E.4.4)

\begin{tabular}{|c|c|c|c|c|c|}
\hline \multirow[t]{2}{*}{ Group } & \multicolumn{4}{|c|}{ Percentage of xanthine oxidase inhibition $(\mu \mathrm{g} / \mathrm{ml})$} & \multirow[t]{2}{*}{$\mathrm{IC}_{50}(\mu \mathrm{g} / \mathrm{ml})$} \\
\hline & 25 & 50 & 100 & 200 & \\
\hline E.3.1 & $15.91 \pm 2.69$ & $18.68 \pm 2.42$ & $30.01 \pm 6.04$ & $33.22 \pm 4.17$ & $>200$ \\
\hline E.3.3 & $15.88 \pm 1.88$ & $22.51 \pm 6.69$ & $25.44 \pm 4.16$ & $28.67 \pm 1.84$ & $>200$ \\
\hline E.4.1 & $5.98 \pm 2.87$ & $13.54 \pm 5.31$ & $15.72 \pm 6.89$ & $15.47 \pm 7.07$ & $>200$ \\
\hline E.4.2 & $7.29 \pm 6.53$ & $6.65 \pm 4.60$ & $11.09 \pm 5.99$ & $19.60 \pm 5.56$ & $>200$ \\
\hline E.4.3 & $22.35 \pm 4.53$ & $25.33 \pm 6.22$ & $32.14 \pm 3.93$ & $41.46 \pm 7.19$ & $>200$ \\
\hline E. 4.4 & $17.59 \pm 4.21$ & $22.38 \pm 6.95$ & $31.38 \pm 3.50$ & $43.20 \pm 9.03$ & $>200$ \\
\hline \multirow[t]{3}{*}{ Allopurinol } & \multicolumn{4}{|c|}{ Percentage of xanthine oxidase inhibition $(\mu \mathrm{g} / \mathrm{ml})$} & $1.08 \pm 0.04$ \\
\hline & 0.2 & 0.5 & 1 & 2 & \\
\hline & $21.93 \pm 4.67$ & $35.28 \pm 6.80$ & $47.66 \pm 3.38$ & $78.02 \pm 2.93$ & \\
\hline
\end{tabular}

Table 5: ${ }^{1} \mathrm{H}$ and ${ }^{13} \mathrm{C}$-NMR chemical shift value for compound $\mathrm{R}$

\begin{tabular}{|c|c|c|c|c|}
\hline Atom position & $\delta^{1} \mathbf{H}(\mathbf{b p j})$ & $\delta^{13} \mathrm{C}(\mathbf{b p j})$ & HSQC $(H \leftrightarrow C)$ & HMBC $(\mathrm{H} \leftrightarrow \mathrm{C})$ \\
\hline 2 & - & 158.58 & & \\
\hline 3 & - & 136.16 & & \\
\hline 4 & - & 179.58 & & \\
\hline 5 & - & 163.19 & & \\
\hline 6 & $6.20(1 \mathrm{H}, d, 2.1 \mathrm{~Hz})$ & 99.95 & C-6 & C-8, C-9, C-10 \\
\hline 7 & - & 166.24 & & \\
\hline 8 & $6.38(1 \mathrm{H}, d, 2.2 \mathrm{~Hz})$ & 94.83 & C-8 & $C-6, C-5, C-10$ \\
\hline 9 & - & 161.62 & & \\
\hline 10 & - & 105.82 & & \\
\hline $1^{\prime}$ & - & 122.60 & & \\
\hline \multirow[t]{2}{*}{$2^{\prime}, 6^{\prime}$} & $7.77(2 \mathrm{H}, d, 8.5 \mathrm{~Hz})$ & 131.88 & $\mathrm{H}-2^{\prime} \leftrightarrow \mathrm{C}-2^{\prime}$ & $C-4^{\prime}, C-6, C-2$ \\
\hline & & & H-6'↔C-6' & $\mathrm{C}-4^{\prime}, \mathrm{C}-2^{\prime}, \mathrm{C}-2$ \\
\hline \multirow[t]{2}{*}{$3^{\prime}, 5^{\prime}$} & $6.94(2 \mathrm{H}, d, 8.5 \mathrm{~Hz})$ & 116.54 & $\mathrm{H}-3^{\prime} \leftrightarrow \mathrm{C}-3^{\prime}$ & $C-4^{\prime}, C-5^{\prime}, C-1^{\prime}$ \\
\hline & & & $\mathrm{H}-5^{\prime} \leftrightarrow \mathrm{C}-5^{\prime}$ & $\mathrm{C}-4^{\prime}, \mathrm{C}-3^{\prime}, \mathrm{C}-1^{\prime}$ \\
\hline $4^{\prime}$ & - & 159.26 & & \\
\hline $\mathrm{Ar}-\mathrm{OH}$ & 4.2 & - & - & - \\
\hline $1 "$ & $5.37(1 \mathrm{H}, \mathrm{s})$ & 103.49 & C-1" & $C-4, C-3, C-3 ", C-5 "$ \\
\hline $2 "$ & $3.72(1 \mathrm{H}, m)$ & 72.04 & $C-2^{\prime}$ & \\
\hline $3 "$ & $3.71(1 \mathrm{H}, m)$ & 73.17 & C-3" & \\
\hline $4 "$ & $3.68(1 \mathrm{H}, m)$ & - & & \\
\hline $5 "$ & $3.65(1 \mathrm{H}, m)$ & 71.91 & C-5” & \\
\hline 6"(CH3) & $0.95(3 \mathrm{H}, d, 4.5 \mathrm{~Hz})$ & 17.65 & C-6" & C-5", C-4" \\
\hline
\end{tabular}

HSQC: Heteronuclear single quantum coherence, HMBC: Heteronuclear multiple bond correlation, NMR: Nuclear magnetic resonance 
kaempferol on XO activity may be due to the insertion of kaempferol into the active site of XO occupied the catalytic center of the enzyme to avoid the entrance of the substrate and induced conformational changes of XO [25]. Kaempferol is presented antihyperuricemic activity in mice hyperuricemic [26].

\section{CONCLUSION}

The subfractions of ethyl acetate fraction which were resulted from subfractionation by a vacuum liquid chromatography and further subfractionation by a classical column chromatography had antihyperuricemic activity in vivo but gave less XO inhibitory activity in vitro. Compound $\mathrm{R}$ in active antihyperuricemic subfraction E.4.3 was kaempferol-3-0-rhamnoside.

\section{ACKNOWLEDGMENT}

We gratefully acknowledge to the Ministry of Research, Technology and Higher Education, Government of Indonesia, for a research grant in the fundamental research program.

\section{REFERENCES}

1. Chen CY, Huang CC, Tsai KC, Huang WJ, Huang WC, Hsu YC, et al. Evaluation of the antihyperuricemic activity of phytochemicals from Davallia formosana by enzyme assay and hyperuricemic mice model. Evid Based Complement Alternat Med 2014;2014:873607.

2. Pacher P, Nivorozhkin A, Szabó C. Therapeutic effects of xanthine oxidase inhibitors: Renaissance half a century after the discovery of allopurinol. Pharmacol Rev 2006;58(1):87-114.

3. Dubchak N, Falasca GF. New and improved strategies for the treatment of gout. Int J Nephrol Renovasc Dis 2010;3:145-66.

4. Kumar A, Azmi W. Phytomedicine: A novel alternative for treatment of gout. Ann Phytomed 2014;3(1):80-8

5. Batchu UR, Mandava K. Biochemical role of xanthine oxidoreductase and its natural inhibitors: An overview. Int $\mathrm{J}$ Pharm Pharm Sci 2016;8(10):57-5

6. Pande I. An update on gout. Indian J Rheumatol 2006;1(2):60-5.

7. Choi HK, Mount DB, Reginato AM; American College of Physicians; American Physiological Society. Pathogenesis of gout. Ann Intern Med 2005;143(7):499-516

8. Hua J, Huang P, Zhu C, Yuan X, Yu CH. Anti-hyperuricemic and nephroprotective effects of modified simiao decoction in hyperuricemic mice. J Ethnopharmacol 2012;142(1):248-52.

9. Ling X, Bochu W. A review of phytotherapy of gout: Perspective of new pharmacological treatments. Pharmazie 2014;69(4):243-56.

10. Sutomo. Decrease of uric acid degree on broiller cock hyperuricaemia by ether petroleum fraction of kepel leaves (Stelechocarpus burahol
Hook). Sains dan Terapan Kimia 2008;2(1):14-22.

11. Heusden EC. Revision of the Southeast Asian genus Stelechocarpus (Annonaceae). Blumea 1995;40:429-38.

12. Heyne K. Medicinal Plants from Indonesia. $2^{\text {nd }}$ ed. Jakarta: Yayasan Sarana Wana Jaya; 1987. p. 765.13

13. Sunarni T, Leviana F, Fidrianny I, Iwo MI, Wirasutisna KR. Antihyperuricemic activity of four plants Annonaceae using hyperuricemic rats model and enzyme assay. Asian J Pharm Clin Res 2015;8(6):250-3

14. Sunarni T, Leviana F, Fidrianny I, Iwo MI, Wirasutisna KR. Antihyperuricemic and xanthine oxidase inhibitory activity of fractions from ethanolic leaves extract of Stelechocarpus burahol. Asian J Pharm Clin Res 2016;9(6):1-4.

15. Sunarni T, Pramono S, Asmah R. Antioxidant free radical scavenging of flavonoid from the leaves of Stelechocarpus burahol (B1.) Hook f. and Th. Indones J Pharm 2007;8(3):111-6.

16. Liu X, Chen R, Shang Y, Jiao B, Huang C. Lithospermic acid as a novel xanthine oxidase inhibitor has anti-inflammatory and hypouricemic effects in rats. Chem Biol Interact 2008;176(2-3):137-42.

17. Umamaheswari M, Asokkumar K, Sivashanmugam AT, Remyaraju A, Subhadradevi V, Ravi TK. In vitro xanthine oxidase inhibitory activity of the fractions of Erythrina stricta Roxb. J Ethnopharmacol 2009; $124: 646-8$

18. Abdullahi A, Hamzah RU, Jigam AA, Yahya A, Kabiru AY, Muhammad $\mathrm{H}$, et al. Inhibitory activity of xanthine oxidase by fractions Crateva adansonii. J Acute Dis 2012;1(2):126-9.

19. Cheng LC, Murugaiyah V, Chan KL. Flavonoids and phenylethanoid glycosides from Lippia nodiflora as promising antihyperuricemic agents and elucidation of their mechanism of action. J Ethnopharmacol 2015; 176:485-93.

20. Dincer HE, Dincer AP, Levinson DJ. Asymptomatic hyperuricemia: To treat or not to treat. Cleve Clin J Med 2002;69(8):594, 597, 600-2.

21. Purwantiningsih, Hakim AR, Purwantini I. Antihyperuricemic activity of the kepel (Stelechocarpus burahol (B1.) Hook. F. and Th.) leaves extract and xanthine oxidase inhibitory study. Int J Pharm Pharm Sci 2010;2(2):122-7.

22. Mabry TJ, Markham KR, Thomas MB. The Systematic Identification of Flavonoid. New York: Springer-Verlag; 1970. p. 1-343.

23. Nagao A, Seki M, Kobayashi H. Inhibition of xanthine oxidase by flavonoids. Biosci Biotechnol Biochem 1999;63(10):1787-90.

24. Ahmad NS, Farman M, Najmi MH, Mian KB, Hasan A. Pharmacological basis for use of Pistacia integerrima leaves in hyperuricemia and gout. J Ethnopharmacol 2008;117(3):478-82

25. Wang Y, Zhang G, Pan J, Gong D. Novel insights into the inhibitory mechanism of kaempferol on xanthine oxidase. J Agric Food Chem 2015;63(2):526-34

26. Mo SF, Zhou F, Lv YZ, Hu QH, Zhang DM, Kong LD. Hypouricemic action of selected flavonoids in mice: Structure-activity relationships. Biol Pharm Bull 2007;30(8):1551-6 